\title{
Article \\ Effects of 24-Epibrassinolide, Bikinin, and Brassinazole on Barley Growth under Salinity Stress Are Genotype- and Dose-Dependent
}

\author{
Jolanta Groszyk ${ }^{1, *(1)}$ and Magdalena Szechyńska-Hebda ${ }^{1,2}$ \\ 1 Plant Breeding and Acclimatization Institute, National Research Institute, 05-870 Błonie, Poland; \\ m.szechynska@ihar.edu.pl \\ 2 The Franciszek Górski Institute of Plant Physiology, Polish Academy of Sciences, 30-239 Kraków, Poland \\ * Correspondence: j.groszyk@ihar.edu.pl; Tel.: +48-22-725-36-50
}

Citation: Groszyk, J.;

Szechyńska-Hebda, M. Effects of 24-Epibrassinolide, Bikinin, and Brassinazole on Barley Growth under Salinity Stress Are Genotype- and Dose-Dependent. Agronomy 2021, 11, 259. https://doi.org/10.3390/ agronomy11020259

Academic Editor: Cordovilla Palomares Received: 11 January 2021

Accepted: 27 January 2021

Published: 30 January 2021

Publisher's Note: MDPI stays neutral with regard to jurisdictional claims in published maps and institutional affiliations.

Copyright: (c) 2021 by the authors. Licensee MDPI, Basel, Switzerland. This article is an open access article distributed under the terms and conditions of the Creative Commons Attribution (CC BY) license (https:/ / creativecommons.org/licenses/by/ $4.0 /)$.

\begin{abstract}
Brassinosteroids (BRs) are involved in the regulation of many plant developmental processes and stress responses. In the presented study, we found a link between plant growth under salinity stress and sensitivity to 24-epibrassinolide (24-EBL, the most active phytohormone belonging to BRs), brassinazole (Brz) and bikinin (inhibitors of BR biosynthesis and signaling pathways, respectively). Plant sensitivity to treatment with active substances and salinity stress was genotypedependent. Cv. Haruna Nijo was more responsive during the lamina joint inclination test, and improved shoot and root growth at lower concentrations of 24-EBL and bikinin under salinity stress, while cv. Golden Promise responded only to treatments of higher concentration. The use of Brz resulted in significant dose-dependent growth inhibition, greater for cv. Haruna Nijo. The results indicated that BR biosynthesis and/or signaling pathways take part in acclimation mechanisms, however, the regulation is complex and depends on internal (genotypic and tissue/organ sensitivity) and external factors (stress). Our results also confirmed that the lamina joint inclination test is a useful tool to define plant sensitivity to BRs, and to BR-dependent salinity stress. The test can be applied to manipulate the growth and stress responses of crops in agricultural practice or to select plants that are sensitive/tolerant to salinity stress in the plant breeding projects.
\end{abstract}

Keywords: lamina joint inclination test; roots growth; shoot growth; BR signaling pathway; Golden Promise; Haruna Nijo

\section{Introduction}

Brassinosteroids (BRs) are a class of plant polyhydroxylated steroid hormones that control plant growth, architecture, leaf size and angle, and seed yield, adjust the processes from seed development through flowering to senescence, or regulate the physiology of stress signaling [1-3]. Over 70 compounds of brassinolide structure were identified in different plant species and their organs [4,5]. The molecular processes of the BRs biosynthesis and signaling pathways were described for arabidopsis (Arabidopsis thaliana L.) and other plant species, including barley (Hordeum vulgare L.) [3]. Nine genes encoding enzymes of BR biosynthetic pathway have been described so far [2,6-10]. The first step of biosynthesis, regulated by DWARF4 (DWF4, also known as CYP90B1), initiates a cascade of reactions that allow for the transformation of episterol into the final product brassinolide (BL) [7]. The BL molecules are captured by a transmembrane receptor Brassinosteroid Insensitive 1-BRI1 Associated Receptor Kinase 1 (BRI1-BAK1) [11]. Binding of BL molecule by BRI1 leads to conformational changes via autophosphorylation of this receptor, disconnection of BRI1 Kinase Inhibitor 1 (BKI1) via transphosphorylation, and association of the BAK1 transmembrane receptor [11-13]. The active BRI1-BAK1 heterodimer initiates a cascade of phosphorylation and dephosphorylation of cytoplasmic relay proteins. Subsequently, BRI1-EMS-Suppressor 1 (BES1) and Brassinazole-Resistant 1 (BZR1) transcription factors 
(TFs) are activated and relocated from the cytoplasm to the nucleus. Dephosphorylation by Protein Phosphatase 2A (PP2A) allows BES1 and BZR1 to function with other TFs and cofactors to promote BR-induced gene expression and inhibit BR-repressed gene expression [14].

The mechanism of BRs' action involves signal transduction pathways from cell surface receptors to the nucleus, where thousands of genes are modulated to confer various biological responses [14], including cell division, elongation, and differentiation. Although a complete picture of the molecular pathways involved is not yet recognized, a study of bul1-1 (boule 1-1) dwarf mutant, recently renamed dwarf7, defective in the BR pathway, revealed that the effect of BR is mediated by an organization of cortical microtubules [15], which are an important driver of both, cell division and cell elongation/differentiation [16].

In addition, BRs gained importance through their potential to regulate a wide range of plant biological processes that enhance tolerance of abiotic stresses [1]. For example, BRs were reported to increase resistance to salinity stress in many plants, including pepper (Capsicum annuum L.) [17], canola (Brassica napus L.) [18], potato (Solanum tuberosum L.) [19], pea (Pisum satioum L.) [20], rice (Oryza sativa L.) [21], and brown mustard (Brassica juncea L.) [22]. The regulatory role of BRs was investigated through the application of bioactive 24-epibrassinolide (24-EBL) or the use of mutants with genetic dissection of BR biosynthesis and signaling pathways $[6,23,24]$. Exogenously applied BRs increased chlorophyll content, $\mathrm{CO}_{2}$ assimilation and quantum yield of photosystem II, ribulose-1, 5-bisphosphate carboxylase/oxygenase (Rubisco) activity, the expression of Rubisco large subunit ( $r b c L$ ) and Rubisco small subunit $(r b c S)$ genes, the level of endogenous hormones, and the total amino acid content $[19,25-28]$. BRs reduced the level of reactive oxygen species (ROS), malondialdehyde (MDA), and ion toxicity [29-32]. They regulate the level of ROS by interacting not only in chloroplasts, but also in mitochondria, since both organelles are the main sources of these oxygen forms $[29,33]$. BR-treated seedlings exposed to salinity stress significantly improved their morphological parameters such as height, root and shoot growth, leaf area, and seedling index [1,34-36]. Contrary to that, moderate dwarf seedlings and severe dwarf adult plants, defective root elongation, dark-green and erect leaves, shortened leaf sheaths, malformed panicles, and shorter grains were found in monocot mutants defective in the molecular functions of BRs e.g., $d 11, d 2, b r d 1, b r d 2$, or $d 61$ [37] and dicot mutants $d w f 1$, dwf4, dim, bri1, bin2-1, cu3, abs, or mtbri1 [2,38-40]. In the case of BR-deficient mutants, these phenotypes could be rescued to the wild type by external application of BRs [14]. Additionally, in recent years, brassinazole (Brz) was used to understand BR function in plants as a complementary tool to BR-deficient mutants. Brz is a triazole compound that inhibits cytochrome P450 steroid C-22 hydroxylase, which is encoded by the DWF4 gene [13] and required for the BR biosynthesis pathway. Brz induces seedling malformation during cultivation in light and dark conditions. Co-application of Brz and 24-EBL allows for maintaining the wild phenotype [41]. Contrary to that, bikinin is a potentially the inhibitor of Glycogen Synthase Kinase 3 (GSK3)/Shaggy-like Serine/Threonine Kinases, which function as negative regulators of BR signaling downstream of BRI1, causing changes similar to those observed in plants after BL treatment and plants overexpressing DWF4 or BRI1 genes [12,42].

There are very few reports concerning genetic variability in barley responses to BRs. Similarly, BR-dependent tolerance of plants to salinity stress has not been studied in detail, particularly under a wide range of concentrations of BRs and their inhibitors. In this study, we report on the links between developmental changes, stress responses and sensitivity to 24-EBL, bikinin, and Brz in two barley cultivars grown under salinity stress.

\section{Materials and Methods}

\subsection{Plant Materials}

The experiments were carried out using grains from single seed descent (SSD) of two barley (Hordeum vulgare L.) cultivars: Golden Promise (provided by Prof. Henryk J. Czembor, IHAR-PIB), and Haruna Nijo (from Gene Bank Dept., CRI Prague-Ruzyně, 
accession number 03C0602168). The spring barley cv. Golden Promise was originally developed from gamma irradiated cv. Maythorpe and released in 1966 (UK) [43]. The origin of elite malting barley cv. Haruna Nijo can be traced to the haplotype of a malting cultivar from Japan introduced more than 100 years ago to Europe [44].

\subsection{Chemicals}

Active substances: 24-epibrassinolide (24-EBL, CAS 78821-43-9, purity $\geq 85 \%$ ), bikinin (CAS 188011-69-0, purity $\geq 98 \%$ ), and brassinazole (Brz, CAS 224047-41-0, purity $\geq 98 \%$ ) were purchased from Sigma-Aldrich (Schnelldorf, Germany). Dilution series of 24-EBL $(0.1 \mu \mathrm{M}, 0.5 \mu \mathrm{M}, 1 \mu \mathrm{M}$, and $5 \mu \mathrm{M}$ for lamina joint inclination test, or $0.0001 \mu \mathrm{M}, 0.001 \mu \mathrm{M}$, $0.01 \mu \mathrm{M}, 0.1 \mu \mathrm{M}$, and $1 \mu \mathrm{M}$ for germination test) were prepared from $1 \mathrm{mM} 24$-EBL stock dissolved in $70 \%$ ethanol (EtOH, POCH, Gliwice, Poland). Dilution series of bikinin (10 $\mu \mathrm{M}$, $50 \mu \mathrm{M}, 100 \mu \mathrm{M}$, and $150 \mu \mathrm{M}$ for lamina joint inclination test, or $1 \mu \mathrm{M}, 10 \mu \mathrm{M}$, and $50 \mu \mathrm{M}$ for germination test) and $\operatorname{Brz}(1 \mu \mathrm{M}, 5 \mu \mathrm{M}, 10 \mu \mathrm{M}$, and $50 \mu \mathrm{M}$ lamina joint inclination test, or $1 \mu \mathrm{M}, 10 \mu \mathrm{M}, 50 \mu \mathrm{M}$ for germination test) were prepared from $18.3 \mathrm{mM}$ and $15.3 \mathrm{mM}$ stock, respectively, dissolved in 100\% dimethyl sulfoxide (DMSO, Sigma-Aldrich). Solvent solutions at a concentration corresponding to the dilution of the reagents were used as controls in all experiments.

\subsection{Lamina Joint Inclination Bioassay}

Genetic variation of two barley cultivars treated with different concentrations of active substances was analyzed using the leaf inclination test, which is a simple bioassay to determine BR activity [45]. Grains of cvs. Golden Promise and Haruna Nijo were incubated on Petri dishes with three layers of the filter paper with spring water (Żywiec-Zdrój S.A., Weegierska Górka, Poland) for $48 \mathrm{~h}$ in a fridge at $4{ }^{\circ} \mathrm{C}$, and $72 \mathrm{~h}$ in an incubator at $23^{\circ} \mathrm{C}$ (darkness in both cases). The 3-day-old seedlings were planted in pots $(16 \mathrm{~cm} \times 22 \mathrm{~cm} \times 8.5 \mathrm{~cm})$ filled with a soil substrate (HolLas, Pasłęk, Poland) and sand (ratio 2:1). They grew 5-6 days in a growth chamber at $20^{\circ} \mathrm{C} / 18^{\circ} \mathrm{C}$, which a photoperiod of $16 \mathrm{~h}$ light with the intensity of about $200 \mu \mathrm{mol}$ photons $\mathrm{m}^{-2} \mathrm{~s}^{-1}$ intensity, and a humidity of $\sim 70 \%$. Plants at the second leaf stage, when the sheath of the first leaf was located $1.0 \pm 0.1 \mathrm{~cm}$ above coleoptile, were used for the experiments. Plant fragments $(2.0 \mathrm{~cm}$ long $) \mathrm{cut} 1.0 \mathrm{~cm}$ above and $1.0 \mathrm{~cm}$ below auricle of the leaves were incubated for 3 days at $23^{\circ} \mathrm{C}$ in darkness in a tube filled with $1 \mathrm{~mL}$ of: deionized water; solvent solutions $(0.7 \% \mathrm{EtOH}$ or $0.5 \% \mathrm{DMSO})$; dilution series of 24-EBL $(0.1 \mu \mathrm{M}, 0.5 \mu \mathrm{M}, 1 \mu \mathrm{M}$, and $5 \mu \mathrm{M})$; bikinin $(10 \mu \mathrm{M}, 50 \mu \mathrm{M}, 100 \mu \mathrm{M}$, and $150 \mu \mathrm{M})$; and $\operatorname{Brz}(1 \mu \mathrm{M}, 5 \mu \mathrm{M}, 10 \mu \mathrm{M}$, and $50 \mu \mathrm{M})$. After incubation the leaves were photographed and average leaf angle was analyzed for five biological replicates with ImageJ $1.51 \mathrm{k}$ software.

\subsection{Growth Parameters}

Ten grains of each cv. Golden Promise and cv. Haruna Nijo were added in a single Petri dish (12 cm $\times 12 \mathrm{~cm}$, with three layers of filter paper) and arranged in a line about $6.0 \mathrm{~cm}$ from the edge of the dish. Petri dishes were filled with $25 \mathrm{~mL}$ of spring water (Żywiec-Zdrój S.A., control conditions) or $150 \mathrm{mM}$ sodium chloride ( $\mathrm{NaCl}$, Roth, Karlsruhe, Germany, salinity stress). The active substances were added: (1) 24-EBL to the final concentration of $0.0001 \mu \mathrm{M}, 0.001 \mu \mathrm{M}, 0.01 \mu \mathrm{M}, 0.1 \mu \mathrm{M}, 1 \mu \mathrm{M}$, or corresponding control solvent solution of $0.07 \% \mathrm{EtOH}$; (2) bikinin to the final concentration of $1 \mu \mathrm{M}, 10 \mu \mathrm{M}$, and $50 \mu \mathrm{M}$ or corresponding control solvent solution of $0.01 \%, 0.07 \%$, and $0.33 \%$; and (3) Brz, to the final concentration of $1 \mu \mathrm{M}, 10 \mu \mathrm{M}$, and $50 \mu \mathrm{M}$ or $0.01 \%, 0.07 \%$, and $0.33 \%$ DMSO. Petri dishes were positioned at a $15^{\circ}$ angle and incubated in the dark for $24 \mathrm{~h}$ in a fridge at $4{ }^{\circ} \mathrm{C}$, then for $72 \mathrm{~h}$ in an incubator at $23^{\circ} \mathrm{C}$, and $48 \mathrm{~h}$ in a growth chamber at $20^{\circ} \mathrm{C} / 18^{\circ} \mathrm{C}$, which a photoperiod of $16 \mathrm{~h}$ light with the intensity of about $200 \mu \mathrm{mol}$ photons $\mathrm{m}^{-2} \mathrm{~s}^{-1}$ intensity, and a humidity of $\sim 70 \%$. Five plants from two Petri dishes and two independent experiments $(n=10)$ were weighed, photographed, and the length of their shoots and roots was measured with ImageJ $1.51 \mathrm{k}$. 


\subsection{Data Analysis}

Statistical analyses (two-way and three-way analysis of variance (ANOVA), Pearson's correlations, and statistical significance of the changes determined by Student's $t$-test or Duncan's analysis, Tables S1-S5) were performed using Microsoft Excel 2016 (Microsoft Office, Warszawa, Poland) and XLSTST (Addinsoft, Paris, France), statistical software for Excel, or Statistica 13.0 (StatSoft, Kraków, Poland). All phenotypical traits are shown as the average of results for five (lamina inclination test) or ten (plant growth parameters) biological replicates with the standard error of the mean. Graphs were generated using Microsoft Excel 2016 and Microsoft PowerPoint 2016 (Microsoft Office).

\section{Results}

\subsection{Cultivar-Dependent Sensitivity to Brassinosteroids}

The sensitivity of two barley cultivars, Golden Promise and Haruna Nijo to 24-EBL, bikinin, and Brz was determined using the lamina joint inclination test. After incubation of plant fragments in 0.1-5 $\mu \mathrm{M}$ 24-EBL (Figure 1a,d) or 10-150 $\mu \mathrm{M}$ bikinin (Figure 1b,e), the angle between leaf sheath and leaf blade increased significantly in comparison with the control incubated in $0.7 \% \mathrm{EtOH}$ or $0.5 \% \mathrm{DMSO}$, respectively, and water-treated control. The increase in the angle was cultivar- and dose-dependent. Cv. Haruna Nijo was significantly $(p<0.000)$ more sensitive to 24-EBL and bikinin than cv. Golden Promise (Table S1b,c), as cv. Haruna Nijo plants responded with a greater lamina angle already at the lowest concentration of active substances $(0.1 \mu \mathrm{M}$ and $10 \mu \mathrm{M}$ for 24-EBL and bikinin, respectively). Cv. Golden Promise improved the angle of lamina inclination only at higher concentrations (Figure 1a, $0.5 \mu \mathrm{M}-5 \mu \mathrm{M} 24$-EBL and Figure $1 \mathrm{~b}, 50 \mu \mathrm{M}-150 \mu \mathrm{M}$ bikinin). In native conditions, this effect is also observed but at later stages of development (untreated plants a few days older than those used for the test) - cv. Haruna Nijo shows a greater angle between the leaf sheath and leaf blade in comparison with cv. Golden Promise (Figure S1). It is also worth noting that during another type of test assessing plant sensitivity to BRs (leaf unrolling test), cv. Haruna Nijo demonstrated greater sensitivity than cv. Golden Promise at the same range of concentration of the active substance (Figure S2). Contrary to that, plants incubated with $5 \mu \mathrm{M}-50 \mu \mathrm{M}$ Brz (Figure 1c,f) had a smaller angle between the leaf sheath and leaf blade than the control leaves incubated in water and the control leaves incubated in DMSO solvent solution. The decrease was already, at lower concentrations, more pronounced for cv. Golden Promise, while dose-dependent changes for cv. Haruna Nijo followed a more regular course ( $p=0.003$, Tables S1d and S2c). Taken together, sensitivity to BRs and their dynamic changes were attributed in a genotype-dependent manner (Table S2).

\subsection{Genotype-Dependent Growth under Salinity Stress}

Under control conditions (watered plants, untreated with active substances), differences in growth i.e., shoot, coleoptile and root length, and fresh weight of cvs. Haruna Nijo and Golden Promise plants were negligible (Figure 2). Salinity stress ( $\mathrm{NaCl}$ treatment, plants untreated with active substances) induced significant $(p<0.0001)$ growth inhibition (Table S1). The most relevant reduction was found in shoot and root length, while coleoptiles were less affected. It also resulted in a significant decrease in total fresh weight. The decline in growth parameters was considerably greater in cv. Haruna Nijo during $\mathrm{NaCl}$ treatment $(40.0 \%, 77.3 \%, 40.8 \%, 41.0 \%$ of watered control plant, for shoot, coleoptile, and root length, and fresh weight, respectively) than in cv. Golden Promise (54.3\%, 89.6\%, $46.8 \%, 63.5 \%$ ), thus indicating greater sensitivity of cv. Haruna Nijo to salinity stress.

\subsection{The Effect of Active Substances on Stress Responses}

Under control conditions (watered plants), cv. Haruna Nijo produced slightly longer shoots (102.6-106.5\%) in the presence of low concentrations of 24-EBL $(0.0001 \mu \mathrm{M}-0.01 \mu \mathrm{M})$, and notably longer coleoptiles (107.7-124.6\%) after treatment with different concentrations of 24-EBL $(0.0001 \mu \mathrm{M}-1 \mu \mathrm{M})$. This effect was not found in cv. Golden Promise and at other 
24-EBL concentrations. Low concentrations of 24-EBL $(0.0001 \mu \mathrm{M}-0.01 \mu \mathrm{M})$ and bikinin $(1 \mu \mathrm{M}-10 \mu \mathrm{M})$ improved root growth in both cultivars (Golden Promise, 106.8-165.0\%; Haruna Nijo 105.4-138.1\%). Higher concentrations of 24-EBL $(1 \mu \mathrm{M})$ and bikinin $(50 \mu \mathrm{M})$ inhibited the plant development (Golden Promise, 68.0-76.3\%; Haruna Nijo 82.1-96.9\%), suggesting toxic effects of the treatments. The use of Brz resulted in significant dosedependent inhibition of growth in both aboveground and belowground organs. However, the reduction in particular parameters was greater for cv. Haruna Nijo (shoot length 59.290.0\%; coleoptile length, 76.9-99.5\%; root length, 59.9-88.3\%; fresh weight, $65.8-86.6 \%$ ) than for cv. Golden Promise (shoot length, 71.1-96.6\%; coleoptile length, 72.0-88.8\%; root length, 63.3-95.6\%; fresh weight, 61.4-95.2\%). Low concentrations of 24-EBL and bikinin applied during salinity stress exerted a protective effect and induced significant $(p<0.02)$ growth improvement in cv. Haruna Nijo $(122.5-128.6 \%$ for different parameters vs. distilled water and/or solvent treatment), but not in cv. Golden Promise (86.8-110.7\%). Higher concentrations of 24-EBL and bikinin were rather harmful and induced growth inhibition, similarly as in plants untreated with $\mathrm{NaCl}$. Brz applied during salinity stress inhibited growth. The reduction was similar for both cultivars at lower Brz levels, but it was considerably greater for cv. Haruna Nijo (21.1-64.1\% for different parameters vs. distilled water and/or solvent treatment) than for cv. Golden Promise (44.8-73.0\%) at the highest concentration of Brz $(50 \mu \mathrm{M})$. Three-way ANOVA indicated that phenotypical traits in the germination test depended on the genotype, growth conditions, and concentration of the treatments $(p<0.001$, Table S4). It is worth noting that DMSO, used in the experiments as a control solvent, slightly influenced shoot and root development but did not suppress the effect of treatments.
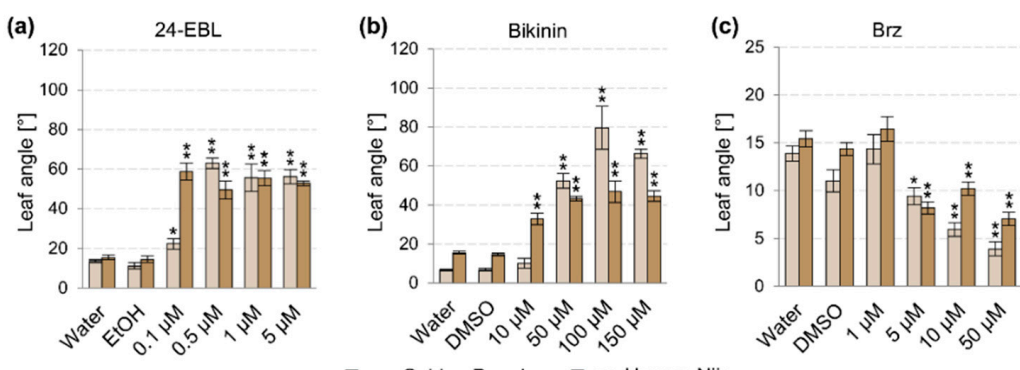

$\square \mathrm{cv}$. Golden Promise $\square \mathrm{cv}$. Haruna Nijo

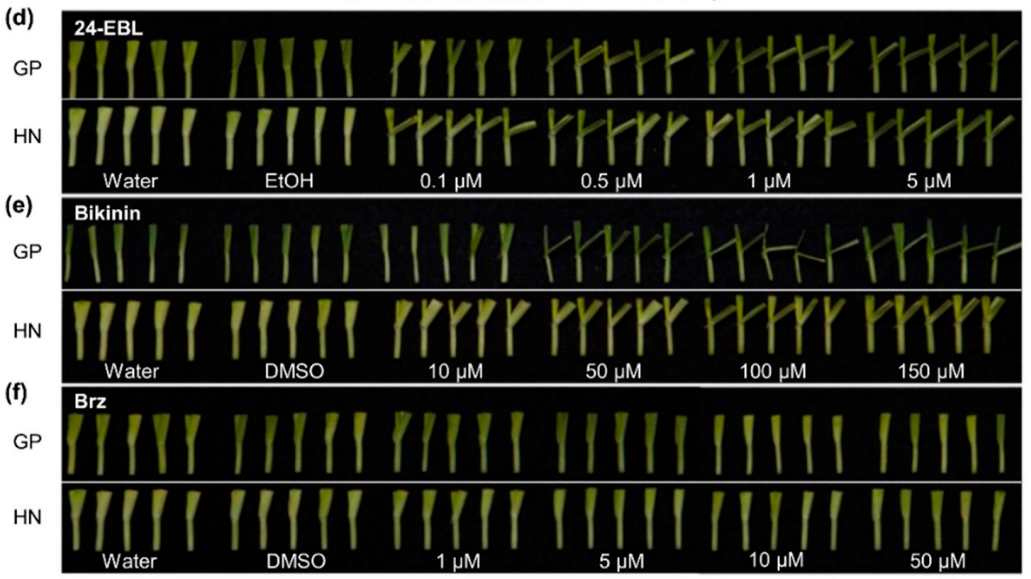

Figure 1. Inclination of the leaf of two barley cultivars Golden Promise (GP) and Haruna Nijo (HN) after treatment with dilution series of 24-EBL $(\mathbf{a}, \mathbf{d})$, bikinin $(\mathbf{b}, \mathbf{e})$, and Brz $(\mathbf{c}, \mathbf{f})$. Data present five biological replicates with a standard error of the mean. The asterisks indicate significant differences from watered control, revealed by Student's $t$-test $\left.{ }^{*}\right) p<0.05,\left({ }^{* *}\right) p<0.005$. $p$-value and two-way ANOVA for genotypes and treatments are presented in Tables S2a and S3, respectively. The image presents five biological replicates. EtOH or DMSO were used as a control of solvent solutions for 24-EBL and bikinin or Brz, respectively. 


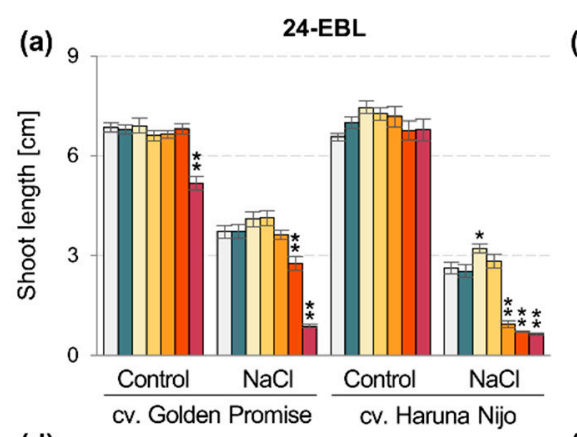

(b)
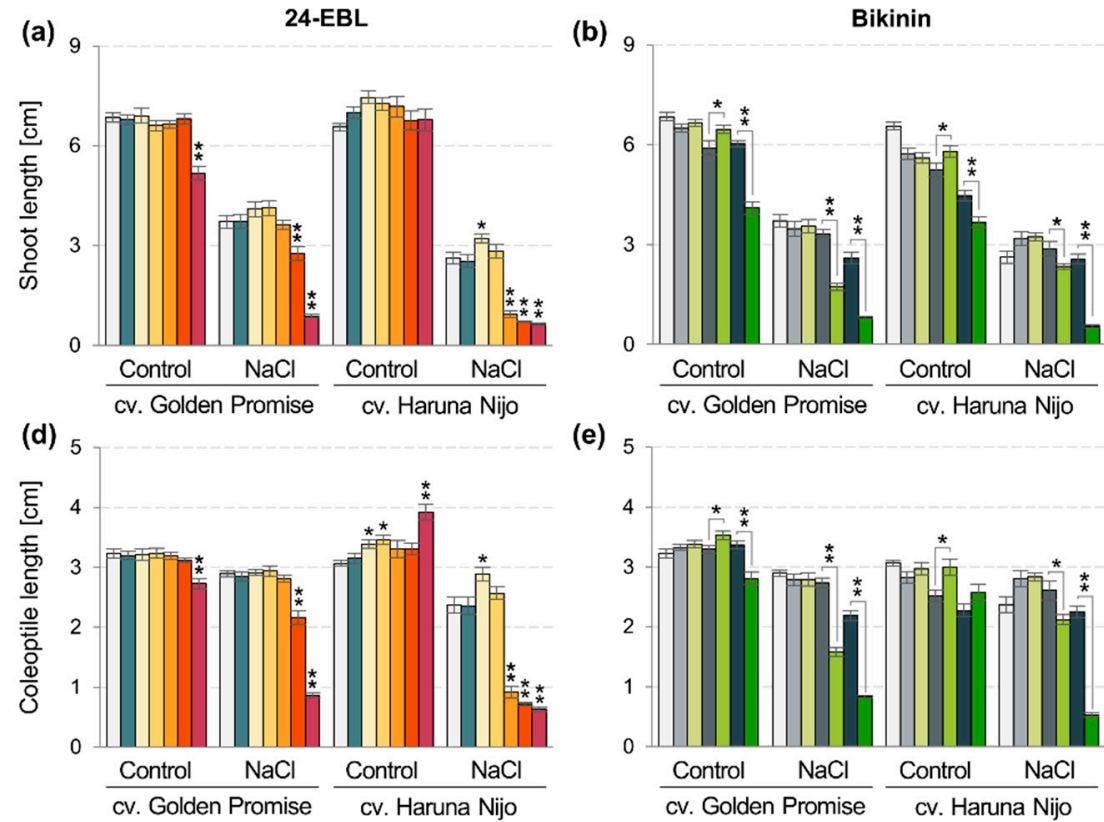

(g) ${ }_{16}$
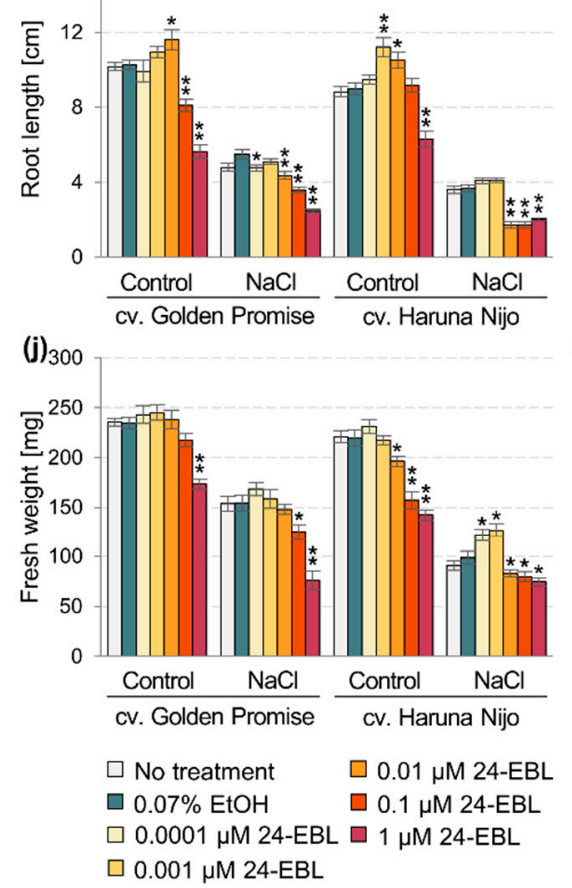

(e) 5

cv. Golden Promise cv. Haruna Nijo

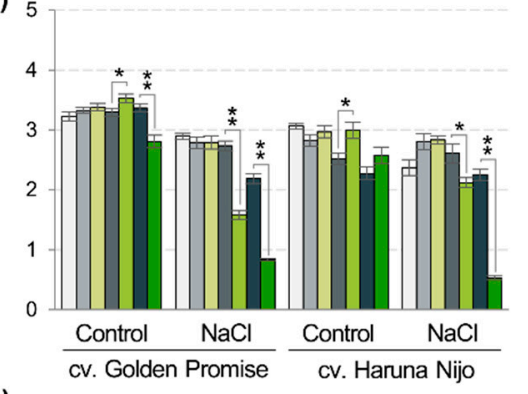

(h) 16
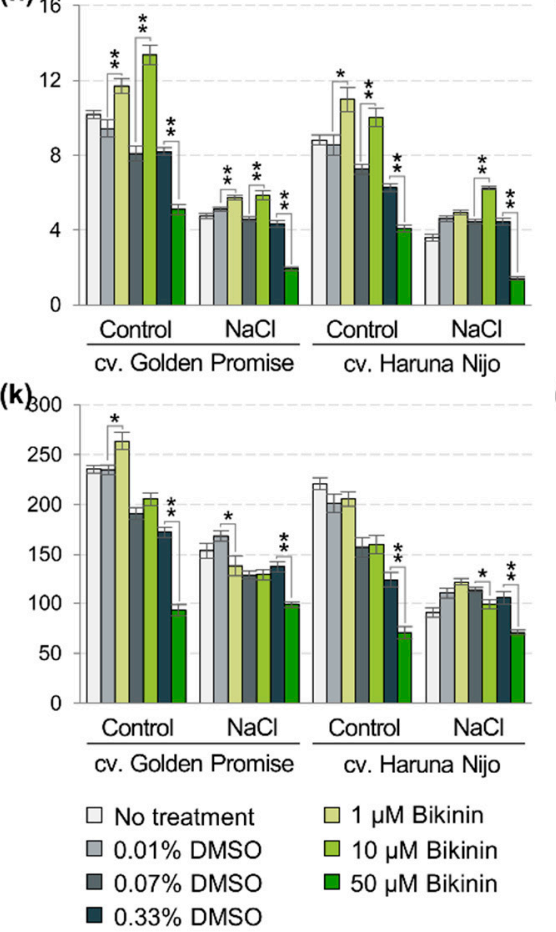

(c) 9

Brz

(f) 5
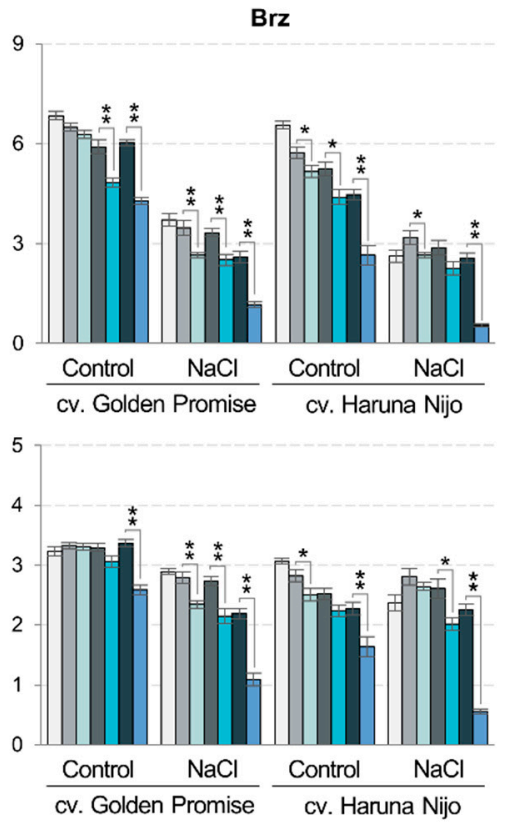

(i) 16

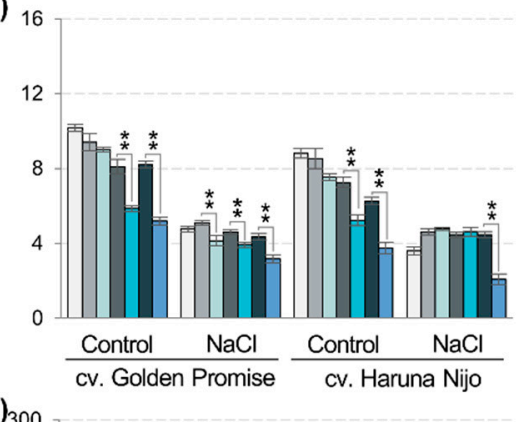

(I) 300

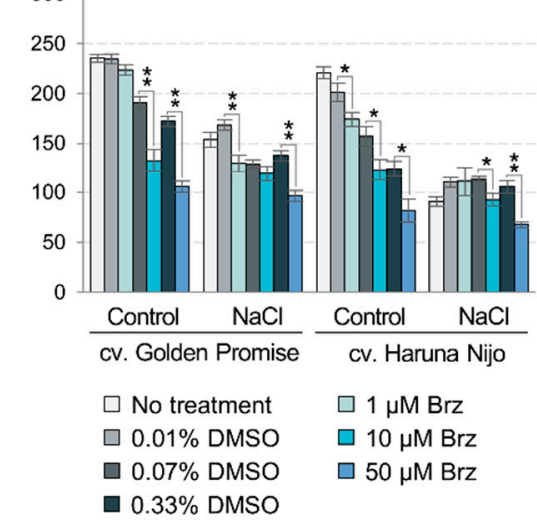

Figure 2. Growth parameters of two barley cultivars Golden Promise and Haruna Nijo after treatment with 24-EBL (a,d,, $\mathbf{g})$ ), bikinin $(\mathbf{b}, \mathbf{e}, \mathbf{h}, \mathbf{k})$, and Brz $(\mathbf{c}, \mathbf{f}, \mathbf{i}, \mathbf{l})$ in control conditions and during salinity stress $(150 \mathrm{mM} \mathrm{NaCl})$. EtOH or DMSO were used as a control of solvent solutions for 24-EBL and bikinin or Brz, respectively. Data presents ten biological replicates with a standard error of the mean. The results of three-way ANOVA are presented in Table S4, while $p$-values for genotypes, salinity levels and treatments are presented in Table S2b,c. The asterisks indicate significant differences from watered control, revealed by Student's $t$-test $\left(^{*}\right) p<0.05,(* *) p<0.005$.

\subsection{Correlation between Sensitivity to Brassinosteroids and Growth}

Cultivar response in the lamina joint inclination test and growth experiments depended on the treatment type and concentration (Tables S3 and S4). To establish the degree to which plant sensitivity to BRs and growth parameters are linearly related in a genotype-dependent (cvs. Golden Promise, Haruna Nijo) and growth condition-dependent (control, salinity stress) manner, the Pearson coefficient was calculated for the applied 
treatments and concentrations (Figure 3, Table S5). Different concentration ranges of the active substances were used in the lamina joint inclination test and the growth experiments (described above). This was necessary, as different developmental phases and different parts of the plants were used in both experiments, and thus the sensitivity of plant material was different. Although BR signaling is tissue-specific, a correlation between the test results and plant growth parameters was demonstrated, separately for both cultivars under control and salinity stress conditions (Figure 3). 24-EBL treatment was a factor that strongly differentiated the cultivar response, as low negative coefficient values were found for cv. Golden Promise and positive correlation values in the range of $0.438-0.685$ were calculated for cv. Haruna Nijo. In this case, reduced correlation values were a consequence of a different growth response at low and high 24-EBL concentration. Similar changes in the value of the correlation coefficient under control conditions and salinity stress was found for bikinin and Brz treatments, with the correlation stronger for bikinin treatment under salinity stress, and for Brz application under control conditions. The correlation for bikinin treatment was the strongest for the lamina joint inclination test and the growth test only for fresh weight under control conditions $(p=0.05)$, while for salinity stress a strong correlation was obtained for shoot and coleoptile length and fresh weight $(p<0.05)$, but not root length. For Brz treatment, the correlation was strong for the lamina joint inclination test and the growth test for all parameters $(p<0.05)$.

\begin{tabular}{|c|c|c|c|c|c|c|c|c|c|}
\hline & & & & & amina joir & & ation test & & \\
\hline & & & 24-EBL & Bikinin & $\mathrm{Brz}$ & & 24-EBL & Bikinin & $\mathrm{Brz}$ \\
\hline & shoot length & & -0.160 & -0.486 & * 0.961 & & -0.157 & ${ }^{*}-0.912$ & 0.565 \\
\hline & coleoptile length & $\stackrel{n}{0}$ & -0.052 & -0.247 & * 0.758 & & -0.117 & * -0.891 & * 0.614 \\
\hline GP & root length & 음 & 0.062 & -0.243 & ** 0.985 & क & -0.110 & -0.397 & 0.673 \\
\hline & fresh weight & 둥 & -0.112 & * -0.704 & * 0.973 & 点 & -0.259 & -0.608 & * 0.734 \\
\hline & shoot length & 8 & * 0.658 & -0.376 & * 0.859 & : & 0.441 & ${ }^{*}-0.719$ & * 0.790 \\
\hline & coleoptile length & 올 & 0.438 & -0.403 & * 0.861 & 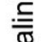 & 0.447 & -0.701 & * 0.857 \\
\hline $\mathrm{HN}$ & root length & 당 & 0.593 & ${ }^{*}-0.563$ & ** 0.981 & & 0.256 & -0.204 & * 0.706 \\
\hline & fresh weight & & * 0.685 & ${ }^{*}-0.724$ & * 0.967 & & 0.372 & ${ }^{*}-0.724$ & 0.447 \\
\hline
\end{tabular}

Figure 3. Linear correlation coefficient between lamina joint inclination test and plant growth parameters in control conditions and during salinity stress. The data in red means negative correlation; green, positive correlation. The asterisks indicate significant correlations revealed by analysis of variance, $\left.\left(^{*}\right) p<0.05,{ }^{* *}\right) p<0.01$ (Table S5).

\section{Discussion}

Our study confirmed a significant role of BRs in promoting plant growth in a genotypedependent manner. We used two barley cultivars: Haruna Nijo, known for its rapidgrowth and intermediate salinity stress tolerance, and Golden Promise, which grows more slower but shows greater resistance to salinity stress $[46,47]$. In our experiments performed in control conditions, the corresponding differences between the cultivars were substantial at later stages of vegetation, particularly in the case of growth and underground biomass accumulation (more than 21 days after germination, Figure S1). At early stages of plant development, variations in the length of shoots, coleoptiles and root fresh weight were negligible (Figure 2), and even reduced growth was observed in cv. Haruna Nijo (Figures S3-S5). Nonetheless, in agreement with previous results, salinity stress more strongly inhibited the growth parameters of cv. Haruna Nijo than of cv. Golden Promise in our experimental system (Table S1). Elongation of shoots and roots was the outcome of cell division and cell differentiation in the apical meristem, while an increase in fresh weight could have resulted from higher water content, which in turn influenced cell expansion. As low concentrations of 24-EBL and bikinin had protective while Brz negative effects on growth parameters of $\mathrm{cv}$. Haruna Nijo during $\mathrm{NaCl}$ stress, we can assume that BRs influenced cell division, differentiation, and/or water uptake. The results for cv. Golden Promise were less notable. This conclusion is reinforced by the fact that relatively low concentrations of BRs induced the signaling pathway eventually leading to the activation of BZR1 transcription factor (TF). The Quiescent Center $(\mathrm{QC})$ of the root meristem is 
regulated by the Brassinosteroids at Vascular and Organizing Center (BRAVO) TF that inhibits QC division [48]. 24-EBL or bikinin treatment can lead to GSK3s deactivation, thus activation of BZR1 TF and inhibition of BRAVO, and finally efficient cell division and root elongation. Considering that root surface area correlated not only with water uptake but also with nutrient uptake potential during stress [49], it can be assumed that better developed roots in cv. Haruna Nijo after treatment with $0.0001 \mu \mathrm{M}-0.001 \mu \mathrm{M} 24-\mathrm{EBL}$ and $10 \mu \mathrm{M}$ bikinin are better supplied with nutrients at the intensive growth stage and under stress conditions, thus dynamics in plant roots can minimize stress [50]. It can act as a feedback mechanism, enabling growth of the above-ground organs and greater $\mathrm{CO}_{2}$ assimilation, and finally increasing availability of photosynthetic products necessary for plant growth $[49,51]$. Specific relocation of photosynthetic products to the places of their direct use can also be considered, as e.g., BRs in grapevine were found to increase soluble sugar content in berries by promoting the activity of invertases and sucrose synthase and by upregulating the expression of genes encoding invertase and mono- and disaccharide transporters [52]. Taken together, BR biosynthesis and/or signaling pathways take part in acclimation mechanisms that enable better plant growth under salinity stress.

So far, only Liu et al. [53] showed the effect of bikinin on lamina joint inclination angle in rice. Our experiments confirmed a strong correlation between plant response and treatment with 24-EBL or bikinin ( 0.915 for cv. Golden Promise and 0.863 for cv. Haruna Nijo). These active substances act at the different steps of BR signaling pathway (Figure 4), but they induced similar responses, including improvement of genotype-dependent growth in control and stress conditions (Figure 2). Moreover, the results indicated that higher tolerance to salinity stress and efficient plant protection after treatment with substances regulating BR signaling pathways can be associated with overall plant sensitivity to BRs (Figure 4). In the lamina joint inclination test, leaf unrolling test, and the growth test, cv. Haruna Nijo was more responsive to 24-EBL and bikinin at low concentrations (Figures 1-3, Figure S2), while cv. Golden Promise responded when the treatments were applied at higher concentrations. This may be due to the fact that endogenously acting BRs are active at a concentration of an order of magnitude smaller compared with the other hormonal substances. In barley leaves of $\mathrm{cv}$. Bowman, castasteron, a representative member of BR group, and 24-EBL were present at a concentration of picograms [54], whereas the other hormones i.e., indole-3-acetic acid (IAA), abscisic acid (ABA), salicylic acid (SA), and jasmonic acid (JA), were detected in nanograms [23]. Therefore, subtle differences in BR content can result in great phenotypic and molecular effects. Finally, our study showed that a wide range of 24 -EBL concentrations $(0.0001 \mu \mathrm{M}-1 \mu \mathrm{M}$ for shoots and coleoptiles; $0.0001 \mu \mathrm{M}-0.1 \mu \mathrm{M}$ for roots) induced growth in control conditions, and a narrow range of 24-EBL concentrations $(0.01 \mu \mathrm{M}-0.01 \mu \mathrm{M})$ improved the growth parameters during salinity stress (Figure 2). A similar trend was found for bikinin $(1 \mu \mathrm{M}-10 \mu \mathrm{M}$ was optimal for enhancement of all parameters in control conditions; $1 \mu \mathrm{M}$ for roots in salinity stress). It can therefore be concluded that a broader range of BR concentrations regulates growth and developmental responses, while a narrow range of BR concentrations is required to induce acclimatization responses. This means that even slight changes in endogenous content of BRs could be signaling and/or regulatory factor of a rapid cellular response, or provide strict control of physiological mechanisms. Several mechanisms have been proposed to explain BR-mediated acclimation to stress, and they involve fine-tuning stress-responsive transcript machinery, activating antioxidant machinery, or promoting production of osmoprotectants [39]. These mechanisms are energy-consuming, which mean efficient energy distribution is necessary during unfavorable conditions to ensure careful coordination of growth and stress responses as well as optimal plant functioning $[55,56]$. However, it is still unclear whether growth limitation represents an energy trade-off or is simply co-regulated with stress responses when stress is severe and plants cease to grow to ensure survival [14]. Different concentration ranges of the substances were optimal to distinguish cultivar sensitivity during the lamina joint inclination test $(0.1 \mu \mathrm{M} 24-\mathrm{EBL}, 10 \mu \mathrm{M}$ bikinin, $10 \mu \mathrm{M}$ Brz, Figure 1) and growth test $(0.0001 \mu \mathrm{M}-0.001 \mu \mathrm{M}$ 24-EBL, $10 \mu \mathrm{M}$ bikinin, and 
$50 \mu \mathrm{M}$ Brz, Figure 2). Additionally, for all tests, low and high concentrations of the active substances evoked different plant responses, both positive and negative (Figure 4). Thus, the study highlighted the complex regulation of BR signaling, multiple points of crosstalk between BRs that depend on internal factors (e.g., genotypes sensitive and resistant to changes in BR concentration, specific tissue/organ sensitivity), external factors (e.g., stress vs. optimal conditions), and a combination of both types of factors (internal regulation of BR content under stress conditions). Indeed, regulation of BES1 and BZR1 was shown to be specific in tissue/organ, developmental, or environmental contexts. BZR1 can interact with plant U-BOX40, degrading BZR1 in roots but not in shoots under low BR content [57]. Similarly, Constitutive Photomorphogenic 1 (COP1) targets the inactive (phosphorylated) form of BZR1 in darkness, while SINA E3 ubiquitin ligases mediate degradation of the active (dephosphorylated) form of BES1 and BZR1 in the light [14,58]. Further, different plant responses to the application of active substances at different concentrations can indicate the existence of separate signal pathways co-regulating the balance between growth and acclimatization reactions or different modulation key molecules in BR signaling pathways. Both statements may be supported by earlier reports that indicate: finely tuned spatiotemporal regulation of $\mathrm{BR}$ signaling with other signaling molecules (crosstalk with auxins, ABA, $\mathrm{H}_{2} \mathrm{O}_{2}$, antioxidants, and osmoprotectant compounds), and modulation of BES1 and BZR1 activity by multiple modes of regulation (oxidation of BES1 and BZR1 by ROS, their inactivation by cytoplasmic sequestration, photoreceptors, or ubiquitination) [14]. Dose-dependent and positive or negative responses of plants to active substances (Figure 4) suggest that, rather than controlling shoot and root growth in a linear fashion, the proper balance of BR levels is crucial for normal root growth and development.

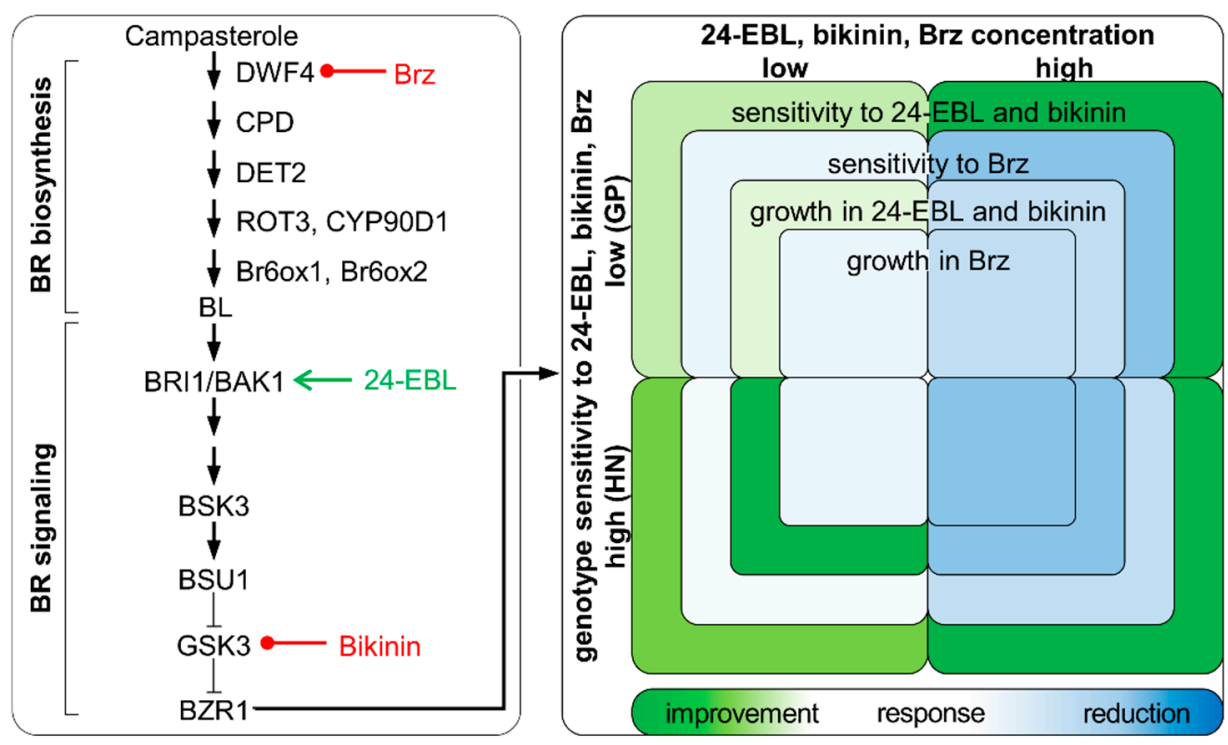

Figure 4. Scheme of selected BRs biosynthesis and signaling pathways, and plant sensitivity to 24-EBL, bikinin, and Brz. The function of active substances is indicated, and the response intensity of cultivars Golden Promise (GP) and Haruna Nijo (HN) to low and high concentrations of active substances during the lamina joint inclination (sensitivity) test and growth experiments during salinity stress are presented.

The results of our experiments suggest that active substances modifying BR biosynthesis and signaling pathways can be applied to manipulate growth and stress responses of crops, with growth-promoting effects observed for lower concentrations, and growth retardation at higher doses (Figures 1 and 2). Treatment with low concentrations of 24-EBL (2.0 $\mathrm{nM}-0.1 \mathrm{nM}$ ) boosted root growth in potato [59], apple seedlings (Malus hupehensis Rehd.) [60], and barley, but high concentrations of 24-EBL $(5.0 \mu \mathrm{M}-0.01 \mu \mathrm{M})$ inhibited rice root development [61]. Similarly, carrot (Daucus carota L.) plants treated with $0.001 \mu \mathrm{M} 24-$ 
EBL had a greater number of petioles and improved aboveground biomass vs. controls [62]. Application of $0.0001 \mu \mathrm{M}$ 24-EBL during salinity stress stimulated stem elongation in potato and enhanced the plant antioxidant enzyme activity (POD, SOD, and CAT) and $\mathrm{K}^{+} / \mathrm{Na}^{+}$content in the stem [59]. Tissue-specific modulation of BR pathways is also known, which is why different concentration ranges of active substances were used in the lamina joint inclination test and growth experiments (Figures 1 and 2). Results published earlier indicated that bikinin at different concentrations could be involved in the growth and development of stomata [63], xylem cell differentiation [64], and lateral root formation [65]. The substances can also be applied to select plants sensitive/tolerant to salinity stress, too. High correlation coefficient was calculated for cultivar sensitivity to 24-EBL, bikinin, and Brz under salinity stress conditions (Figures 2 and 3). Two rice cultivars, Dongjin and Nipponbare, responded in the same way during the leaf lamina joint inclination test and germination test in $1 \mu \mathrm{M}$ 24-EBL solutions [66]. According to our knowledge, this is the first report on concentration-dependent BR activity tested under optimal and salinity stress conditions. Earlier works usually used limited concentration ranges of the active substances, which may be insufficient to determine BR-dependent signaling and plant responses during salinity stress. Altogether, our results indicate that testing individual substances or preferably groups of substances may be a useful selection tool for plant breeding, while their application in native conditions can be considered a supportive technique for agriculture and plant cultivation in dry and high salinity regions. However, their concentration should be carefully chosen and optimized each time to ensure proper activity of the substances and result interpretation.

\section{Conclusions}

BRs can promote plant growth in a genotype-dependent manner in optimal and stress conditions. During salinity stress, low concentrations of 24-EBL and bikinin have a protective effect and enable better plant and especially root growth, while Brz brings about detrimental effects. This indicates that BR biosynthesis and/or signaling pathways take part in acclimation mechanisms. A broader range of BR concentrations regulates growth and developmental responses, while their narrow range is required to induce acclimatization responses. Regulation of BR signaling is complex and depends on internal factors (genotypic and tissue/organ sensitivity), external factors (stress), and a combination thereof. Our results suggest that 24-EBL or bikinin may inhibit GSK3, and the hypothesis will be verified in future studies using specific antibodies. The lamina joint inclination test is a useful tool to define plant sensitivity to BRs and BRs-dependent salinity stress. The test can be applied to manipulate growth and stress responses of crops in agricultural practice or to select plants that are sensitive/tolerant to salinity stress in the plant breeding process. We plan to test BRs to see the differences in a grain yield and confirm the effectiveness of exogenous phytohormonal application to improve barley productivity in the field.

Supplementary Materials: The following are available online at https:/ / www.mdpi.com/2073-439 5/11/2/259/s1, Figure S1: Phenotype of 11 (a) and 21 (b) days-old cultivars Golden Promise and Haruna Nijo plants., Figure S2: Leaf-blade segments after 24-EBL treatment during the unrolling test. Unrolling test was performed for two barley cultivars. Golden Promise (GP) and Haruna Nijo $(\mathrm{HN})$. The incubation of $1 \mathrm{~cm}$ long leaf fragments was performed in water, EtOH-treated control, and 24-EBL dilution series. Data present ten biological replicates with a standard error of the mean. The asterisks indicate significant differences from watered control, revealed by Student's $t$-test $\left(^{*}\right) p<0.05$, $\left.{ }^{* *}\right) p<0.005$., Figure S3: Phenotype of barley cultivars Golden Promise and Haruna Nijo after treatment with dilution series of 24-EBL in control (a) and salinity stress (150 mM NaCl) conditions (b). Photographs present three biological replicates. EtOH was used as a control of solvent solutions for 24-EBL. Scale bar: $10 \mathrm{~cm}$., Figure S4: Phenotype of barley cultivars Golden Promise and Haruna Nijo after treatment with dilution series of bikinin in control (a) and salinity stress (150 $\mathrm{mM} \mathrm{NaCl})$ conditions (b). Photographs present three biological replicates. DMSO was used as a control of solvent solutions for bikinin. Scale bar: $10 \mathrm{~cm}$., Figure S5: Phenotype of barley cultivars Golden Promise and Haruna Nijo after treatment with dilution series of Brz in control (a) and salinity stress 
$(150 \mathrm{mM} \mathrm{NaCl})$ conditions (b). Photography presents three biological replicates. DMSO was used as a control of solvent solutions for Brz. Scale bar: $10 \mathrm{~cm}$., Table S1: Duncan's test for the lamina joint inclination bioassays (a) and plant growth experiment: 24-EBL (b), bikinin (c), and Brz (d), Table S2. $p$-values for lamina joint inclination bioassays (a) and plant growth parameters in control conditions and during salinity stress treatments for 24-EBL (b), bikinin (c), and Brz (d) that are presented in Figures $1 \mathrm{a}$ and $2 \mathrm{~b}-\mathrm{d}$, Table S3. Two-way ANOVA for lamina joint inclination test for 24-EBL (a), bikinin (b), and Brz (c) presented in Figure 1, Table S4. Three-way ANOVA for phenotypical traits for 24-EBL (a), bikinin (b), and Brz (c) presented in Figure 2, Table S5. p-values for linear correlation between lamina joint inclination test and plant growth parameters in control conditions and during salinity stress, that is presented in Figure 3.

Author Contributions: Conceptualization, J.G. and M.S.-H.; methodology, J.G.; validation, J.G.; investigation, J.G.; data curation, J.G. and M.S.-H.; writing-original draft preparation, J.G. and M.S.-H.; writing-review and editing, J.G. and M.S.-H.; visualization, J.G. and M.S.-H.; supervision, M.S.-H.; funding acquisition, J.G. All authors have read and agreed to the published version of the manuscript.

Funding: This research received no external funding.

Institutional Review Board Statement: Not applicable.

Informed Consent Statement: Not applicable.

Data Availability Statement: Data are contained within the article or supplementary material.

Conflicts of Interest: The authors declare no conflict of interest.

\section{References}

1. Anwar, A.; Liu, Y.; Dong, R.; Bai, L.; Yu, X.; Li, Y. The physiological and molecular mechanism of brassinosteroid in response to stress: A review. Biol. Res. 2018, 51, 46. [CrossRef] [PubMed]

2. Castorina, G.; Consonni, G. The role of brassinosteroids in controlling plant height in Poaceae: A genetic perspective. Int. J. Mol. Sci. 2020, 21, 1191. [CrossRef] [PubMed]

3. Gruszka, D. Exploring the brassinosteroid signaling in monocots reveals novel components of the pathway and implications for plant breeding. Int. J. Mol. Sci. 2020, 21, 354. [CrossRef] [PubMed]

4. Bajguz, A. Metabolism of brassinosteroids in plants. Plant Physiol. Biochem. 2007, 45, 95-107. [CrossRef] [PubMed]

5. Shimada, Y.; Goda, H.; Nakamura, A.; Takatsuto, S.; Fujioka, S.; Yoshida, S. Organ-specific expression of brassinosteroidbiosynthetic genes and distribution of endogenous brassinosteroids in Arabidopsis. Plant Physiol. 2003, 131, 287-297. [CrossRef]

6. Dockter, C.; Gruszka, D.; Braumann, I.; Druka, A.; Druka, I.; Franckowiak, J.; Gough, S.P.; Janeczko, A.; Kurowska, M.; Lundqvist, J.; et al. Induced variations in brassinosteroid genes define barley height and sturdiness, and expand the green revolution genetic toolkit. Plant Physiol. 2014, 166, 1912-1927. [CrossRef]

7. Gruszka, D.; Szarejko, I.; Maluszynski, M. Identification of barley DWARF gene involved in brassinosteroid synthesis. Plant Growth Regul. 2011, 65, 343-358. [CrossRef]

8. Makarevitch, I.; Thompson, A.; Muehlbauer, G.J.; Springer, N.M. Brd1 gene in maize encodes a brassinosteroid C-6 oxidase. PLoS ONE 2012, 7, e30798. [CrossRef]

9. Hartwig, T.; Chuck, G.S.; Fujioka, S.; Klempien, A.; Weizbauer, R.; Potluri, D.P.V.; Choe, S.; Johal, G.S.; Schulz, B. Brassinosteroid control of sex determination in maize. Proc. Natl. Acad. Sci. USA 2011, 108, 19814-19819. [CrossRef]

10. Liu, T.; Zhang, J.; Wang, M.; Wang, Z.; Li, G.; Qu, L.; Wang, G. Expression and functional analysis of ZmDWF4, an ortholog of Arabidopsis DWF4 from maize (Zea mays L.). Plant. Cell Rep. 2007, 26, 2091-2099. [CrossRef]

11. Nam, K.H.; Li, J. BRI1/BAK1, a receptor kinase pair mediating brassinosteroid signaling. Cell 2002, 110, 203-212. [CrossRef]

12. Li, J.; Nam, K.H. Regulation of brassinosteroid signaling by a GSK3/SHAGGY-like kinase. Science 2002, 295, 1299-1301. [PubMed]

13. Wang, X.; Li, X.; Meisenhelder, J.; Hunter, T.; Yoshida, S.; Asami, T.; Chory, J. Autoregulation and homodimerization are involved in the activation of the plant steroid receptor BRI1. Dev. Cell 2005, 8, 855-865. [CrossRef] [PubMed]

14. Nolan, T.M.; Vukašinović, N.; Liu, D.; Russinova, E.; Yin, Y. Brassinosteroids: Multidimensional regulators of plant growth, development, and stress responses. Plant Cell 2020, 32, 295-318. [CrossRef]

15. Catterou, M.; Dubois, F.; Schaller, H.; Aubanelle, L.; Vilcot, B.; Sangwan-Norreel, B.S.; Sangwan, R.S. Brassinosteroids, microtubules and cell elongation in Arabidopsis thaliana. II. Effects of brassinosteroids on microtubules and cell elongation in the bul1 mutant. Planta 2001, 212, 673-683. [CrossRef]

16. Szechyńska-Hebda, M.; Wędzony, M.; Dubas, E.; Kieft, H.; van Lammeren, A. Visualisation of microtubules and actin filaments in fixed BY-2 suspension cells using an optimised whole mount immunolabelling protocol. Plant Cell Rep. 2006, 25, 758-766. [CrossRef] 
17. Abbas, S.; Latif, H.H.; Elsherbiny, E.A. Effect of 24-epibrassinolide on the physiological and genetic changes on two varieties of pepper under salt stress conditions. Pak. J. Bot. 2013, 45, 1273-1284.

18. Liu, J.; Gao, H.; Wang, X.; Zheng, Q.; Wang, C.; Wang, X.; Wang, Q. Effects of 24-epibrassinolide on plant growth, osmotic regulation and ion homeostasis of salt-stressed canola. Plant. Biol. 2014, 16, 440-450. [CrossRef]

19. Kolomeichuk, L.V.; Efimova, M.V.; Zlobin, I.E.; Kreslavski, V.D.; Ol'ga, K.M.; Kovtun, I.S.; Khripach, V.A.; Kuznetsov, V.V.; Allakhverdiev, S.I. 24-Epibrassinolide alleviates the toxic effects of $\mathrm{NaCl}$ on photosynthetic processes in potato plants. Photosynth. Res. 2020, 146, 151-163. [CrossRef]

20. Shahid, M.; Pervez, M.; Balal, R.; Mattson, N.; Rashid, A.; Ahmad, R.; Ayyub, C.; Abbas, T. Brassinosteroid (24-epibrassinolide) enhances growth and alleviates the deleterious effects induced by salt stress in pea (Pisum sativum L.). Aust. J. Crop. Sci. 2011, 5 , 500 .

21. Anuradha, S.; Rao, S.S.R. Application of brassinosteroids to rice seeds (Oryza sativa L.) reduced the impact of salt stress on growth, prevented photosynthetic pigment loss and increased nitrate reductase activity. Plant Growth Regul. 2003, 40, 29-32. [CrossRef]

22. Ali, B.; Hayat, S.; Fariduddin, Q.; Ahmad, A. 24-Epibrassinolide protects against the stress generated by salinity and nickel in Brassica juncea. Chemosphere 2008, 72, 1387-1392. [CrossRef] [PubMed]

23. Gruszka, D.; Janeczko, A.; Dziurka, M.; Pociecha, E.; Oklestkova, J.; Szarejko, I. Barley brassinosteroid mutants provide an insight into phytohormonal homeostasis in plant reaction to drought stress. Front. Plant Sci. 2016, 7, 1824. [CrossRef] [PubMed]

24. Janeczko, A.; Biesaga-Kościelniak, J.; Oklešt'ková, J.; Filek, M.; Dziurka, M.; Szarek-Łukaszewska, G.; Kościelniak, J. Role of 24-epibrassinolide in wheat production: Physiological effects and uptake. J. Agron. Crop. Sci. 2010, 196, 311-321. [CrossRef]

25. Xia, X.-J.; Huang, L.-F.; Zhou, Y.-H.; Mao, W.-H.; Shi, K.; Wu, J.-X.; Asami, T.; Chen, Z.; Yu, J.-Q. Brassinosteroids promote photosynthesis and growth by enhancing activation of Rubisco and expression of photosynthetic genes in Cucumis sativus. Planta 2009, 230, 1185. [CrossRef]

26. Zhao, G.; Xu, H.; Zhang, P.; Su, X.; Zhao, H. Effects of 2, 4-epibrassinolide on photosynthesis and Rubisco activase gene expression in Triticum aestivum L. seedlings under a combination of drought and heat stress. Plant Growth Regul. 2017, 81, 377-384. [CrossRef]

27. Janeczko, A.; Gruszka, D.; Pociecha, E.; Dziurka, M.; Filek, M.; Jurczyk, B.; Kalaji, H.M.; Kocurek, M.; Waligorski, P. Physiological and biochemical characterisation of watered and drought-stressed barley mutants in the HvDWARF gene encoding C6-oxidase involved in brassinosteroid biosynthesis. Plant Physiol. Biochem. 2016, 99, 126-141. [CrossRef]

28. Janeczko, A.; Oklešt'ková, J.; Pociecha, E.; Kościelniak, J.; Mirek, M. Physiological effects and transport of 24-epibrassinolide in heat-stressed barley. Acta Physiol. Plant. 2010, 33, 1249-1259. [CrossRef]

29. Derevyanchuk, M.; Kretynin, S.; Iakovenko, O.; Litvinovskaya, R.; Zhabinskii, V.; Martinec, J.; Blume, Y.; Khripach, V.; Kravets, V. Effect of 24-epibrassinolide on Brassica napus alternative respiratory pathway, guard cells movements and phospholipid signaling under salt stress. Steroids 2017, 117, 16-24. [CrossRef]

30. Cui, X.-Y.; Gao, Y.; Guo, J.; Yu, T.-F.; Zheng, W.-J.; Liu, Y.-W.; Chen, J.; Xu, Z.-S.; Ma, Y.-Z. BES/BZR transcription factor TaBZR2 positively regulates drought responses by activation of TaGST1. Plant Physiol. 2019, 180, 605-620. [CrossRef]

31. Sharma, P.; Bhardwaj, R. Effects of 24-epibrassinolide on growth and metal uptake in Brassica juncea L. under copper metal stress. Acta Physiol. Plant. 2007, 29, 259-263. [CrossRef]

32. Zhong, W.; Xie, C.; Hu, D.; Pu, S.; Xiong, X.; Ma, J.; Sun, L.; Huang, Z.; Jiang, M.; Li, X. Effect of 24-epibrassinolide on reactive oxygen species and antioxidative defense systems in tall fescue plants under lead stress. Ecotoxicol. Environ. Saf. 2020, 187, 109831. [CrossRef] [PubMed]

33. Derevyanchuk, M.; Kretynin, S.; Kolesnikov, Y.; Litvinovskaya, R.; Martinec, J.; Khripach, V.; Kravets, V. Seed germination, respiratory processes and phosphatidic acid accumulation in Arabidopsis diacylglycerol kinase knockouts-The effect of brassinosteroid, brassinazole and salinity. Steroids 2019, 147, 28-36. [CrossRef] [PubMed]

34. Talaat, N.B.; Shawky, B.T. 24-Epibrassinolide alleviates salt-induced inhibition of productivity by increasing nutrients and compatible solutes accumulation and enhancing antioxidant system in wheat (Triticum aestivum L.). Acta Physiol. Plant. 2013, 35, 729-740. [CrossRef]

35. Zhang, H. Effects of priming with sodium nitroprusside and 24-epibrassinolide or salylic acid on seed germination and growth of maize under salt stress. J. Nucl. Agric. Sci. 2012, 1.

36. Wu, X.; Zha, D.; Zhu, Z.; Li, X. Effects of exogenous 24-epibrassinolide on seed germination, physiological characteristics of eggplant seedlings under $\mathrm{NaCl}$ stress. Plant Physiol. Commun. 2011, 47, 607-612.

37. Hong, Z.; Ueguchi-Tanaka, M.; Fujioka, S.; Takatsuto, S.; Yoshida, S.; Hasegawa, Y.; Ashikari, M.; Kitano, H.; Matsuoka, M. The rice brassinosteroid-deficient dwarf2 mutant, defective in the rice homolog of Arabidopsis DIMINUTO/DWARF1, is rescued by the endogenously accumulated alternative bioactive brassinosteroid, dolichosterone. Plant. Cell 2005, 17, 2243-2254. [CrossRef]

38. Bishop, G.J. Brassinosteroid mutants of crops. J. Plant Growth Regul. 2003, 22, 325-335. [CrossRef]

39. Planas-Riverola, A.; Gupta, A.; Betegón-Putze, I.; Bosch, N.; Ibañes, M.; Caño-Delgado, A.I. Brassinosteroid signaling in plant development and adaptation to stress. Development 2019, 146, 5. [CrossRef]

40. Chaiwanon, J.; Wang, Z.-Y. Spatiotemporal brassinosteroid signaling and antagonism with auxin pattern stem cell dynamics in Arabidopsis roots. Curr. Biol. 2015, 25, 1031-1042. [CrossRef]

41. Asami, T.; Min, Y.K.; Nagata, N.; Yamagishi, K.; Takatsuto, S.; Fujioka, S.; Murofushi, N.; Yamaguchi, I.; Yoshida, S. Characterization of brassinazole, a triazole-type brassinosteroid biosynthesis inhibitor. Plant Physiol. 2000, 123, 93-100. [CrossRef] [PubMed] 
42. Youn, J.-H.; Kim, T.-W. Functional insights of plant GSK3-like kinases: Multi-taskers in diverse cellular signal transduction pathways. Mol. Plant 2015, 8, 552-565. [CrossRef] [PubMed]

43. Forster, B.P. Mutation genetics of salt tolerance in barley: An assessment of Golden Promise and other semi-dwarf mutants. Euphytica 2001, 120, 317-328. [CrossRef]

44. Hisano, H.; Tsujimura, M.; Yoshida, H.; Terachi, T.; Sato, K. Mitochondrial genome sequences from wild and cultivated barley (Hordeum vulgare). BMC Genom. 2016, 17, 824. [CrossRef] [PubMed]

45. Wada, K.; Marumo, S.; Ikekawa, N.; Morisaki, M.; Mori, K. Brassinolide and homobrassinolide promotion of lamina inclination of rice seedlings. Plant Cell Physiol. 1981, 22, 323-325.

46. Adem, G.D.; Roy, S.J.; Zhou, M.; Bowman, J.P.; Shabala, S. Evaluating contribution of ionic, osmotic and oxidative stress components towards salinity tolerance in barley. BMC Plant Biol. 2014, 14, 113. [CrossRef]

47. Matsumoto, T.; Tanaka, T.; Sakai, H.; Amano, N.; Kanamori, H.; Kurita, K.; Kikuta, A.; Kamiya, K.; Yamamoto, M.; Ikawa, H.; et al. Comprehensive sequence analysis of 24,783 barley full-length cDNAs derived from 12 clone libraries. Plant Physiol. 2011, 156, 20-28. [CrossRef]

48. Vilarrasa-Blasi, J.; González-García, M.-P.; Frigola, D.; Fàbregas, N.; Alexiou, K.G.; López-Bigas, N.; Rivas, S.; Jauneau, A.; Lohmann, J.U.; Benfey, P.N. Regulation of plant stem cell quiescence by a brassinosteroid signaling module. Dev. Cell 2014, 30, 36-47. [CrossRef]

49. Grzesiak, S.; Hordyńska, N.; Szczyrek, P.; Grzesiak, M.T.; Noga, A.; Szechyńska-Hebda, M. Variation among wheat (Triticum easativum L.) genotypes in response to the drought stress: I-selection approaches. J. Plant. Interact. 2019, 14, 30-44. [CrossRef]

50. Arsova, B.; Foster, K.J.; Shelden, M.C.; Bramley, H.; Watt, M. Dynamics in plant roots and shoots minimize stress, save energy and maintain water and nutrient uptake. New Phytol. 2020, 225, 1111-1119. [CrossRef]

51. Dąbrowska-Bronk, J.; Komar, D.N.; Rusaczonek, A.; Kozłowska-Makulska, A.; Szechyńska-Hebda, M.; Karpiński, S. $\beta$-carbonic anhydrases and carbonic ions uptake positively influence Arabidopsis photosynthesis, oxidative stress tolerance and growth in light dependent manner. J. Plant Physiol. 2016, 203, 44-54. [CrossRef]

52. Xu, F.; Xi, Z.-M.; Zhang, H.; Zhang, C.-J.; Zhang, Z.-W. Brassinosteroids are involved in controlling sugar unloading in Vitis vinifera 'Cabernet Sauvignon' berries during véraison. Plant Physiol. Biochem. 2015, 94, 197-208. [CrossRef] [PubMed]

53. Liu, S.; Yu, C.; Tian, H.; Hu, T.; He, Y.; Li, Z.; Tan, W.; Zhang, L.; Duan, L. A novel bikinin analogue for Arabidopsis and rice with superior plant growth-promoting activity. J. Plant Growth Regul. 2018, 37, 166-173. [CrossRef]

54. Sadura, I.; Pociecha, E.; Dziurka, M.; Oklestkova, J.; Novak, O.; Gruszka, D.; Janeczko, A. Mutations in the HvDWARF, HvCPD and HvBRI1 genes-involved in brassinosteroid biosynthesis/signalling: Altered photosynthetic efficiency, hormonal homeostasis and tolerance to high/low temperatures in barley. J. Plant Growth Regul. 2019, 38, 1062-1081. [CrossRef]

55. Szechyńska-Hebda, M.; Lewandowska, M.; Karpiński, S. Electrical signaling, photosynthesis and systemic acquired acclimation. Front. Physiol. 2017, 8, 684. [CrossRef]

56. Dyda, M.; Wąsek, I.; Tyrka, M.; Wędzony, M.; Szechyńska-Hebda, M. Local and systemic regulation of PSII efficiency in triticale infected by the hemibiotrophic pathogen Microdochium nivale. Physiol. Plant. 2019, 165, 711-727. [CrossRef]

57. Kim, E.-J.; Lee, S.-H.; Park, C.-H.; Kim, S.-H.; Hsu, C.-C.; Xu, S.; Wang, Z.-Y.; Kim, S.-K.; Kim, T.-W. Plant U-box40 mediates degradation of the brassinosteroid-responsive transcription factor BZR1 in Arabidopsis roots. Plant. Cell 2019, 31, 791-808. [CrossRef]

58. Yang, M.; Wang, X. Multiple ways of BES1/BZR1 degradation to decode distinct developmental and environmental cues in plants. Mol. Plant. 2017, 10, 915-917. [CrossRef]

59. Hu, Y.; Xia, S.; Su, Y.; Wang, H.; Luo, W.; Su, S.; Xiao, L. Brassinolide increases potato root growth in vitro in a dose-dependent way and alleviates salinity stress. BioMed Res. Int. 2016, 2016, 8231873. [CrossRef]

60. Mao, J.; Zhang, D.; Li, K.; Liu, Z.; Liu, X.; Song, C.; Li, G.; Zhao, C.; Ma, J.; Han, M. Effect of exogenous brassinolide (BR) application on the morphology, hormone status, and gene expression of developing lateral roots in Malus hupehensis. Plant Growth Regul. 2017, 82, 391-401. [CrossRef]

61. Tang, Y.; Liu, H.; Guo, S.; Wang, B.; Li, Z.; Chong, K.; Xu, Y. OsmiR396d affects gibberellin and brassinosteroid signaling to regulate plant architecture in rice. Plant Physiol. 2018, 176, 946-959. [CrossRef] [PubMed]

62. Que, F.; Wang, G.-L.; Xu, Z.-S.; Wang, F.; Xiong, A.-S. Transcriptional regulation of brassinosteroid accumulation during carrot development and the potential role of brassinosteroids in petiole elongation. Front. Plant Sci. 2017, 8, 1356. [CrossRef] [PubMed]

63. Kim, T.-W.; Michniewicz, M.; Bergmann, D.C.; Wang, Z.-Y. Brassinosteroid regulates stomatal development by GSK3-mediated inhibition of a MAPK pathway. Nature 2012, 482, 419-422. [CrossRef] [PubMed]

64. Kondo, Y.; Ito, T.; Nakagami, H.; Hirakawa, Y.; Saito, M.; Tamaki, T.; Shirasu, K.; Fukuda, H. Plant GSK3 proteins regulate xylem cell differentiation downstream of TDIF-TDR signalling. Nat. Commun. 2014, 5, 1-11. [CrossRef] [PubMed]

65. Cho, H.; Ryu, H.; Rho, S.; Hill, K.; Smith, S.; Audenaert, D.; Park, J.; Han, S.; Beeckman, T.; Bennett, M.J. A secreted peptide acts on BIN2-mediated phosphorylation of ARFs to potentiate auxin response during lateral root development. Nat. Cell Biol. 2014, 16, 66. [CrossRef]

66. Wang, K.; Li, M.-Q.; Chang, Y.-P.; Zhang, B.; Zhao, Q.-Z.; Zhao, W.-1. The basic helix-loop-helix transcription factor OsBLR1 regulates leaf angle in rice via brassinosteroid signalling. Plant Mol. Biol. 2020, 102, 589-602. [CrossRef] 